\title{
ZE SÖMMERINGA: O ORGÁNU DUŠE ${ }^{1}$
}

\section{Immanuel Kant}

Vážený pane, předkládáte mi k posouzení své dokončené dílo pojednávající o jistém principu životní síly v tělech živočichů, který je nazýván, pokud jde o pouhou schopnost vnímání, bezprostředním smyslovým nástrojem ( $\pi \rho \tilde{\omega} \tau o v \alpha i \sigma \theta \eta \tau$ prov), zatímco pokud jde o sjednocení veškerých vjemů v jisté části mozku, společným místem počitků (sensorium commune): tuto poctu, nakolik je mi prokazována jako někomu, kdo není zcela nezkušený v prírodovědě, prrijímám s díkem. - Avšak pojí se s tím navíc otázka týkající se metafyziky (jejíž orákulum, jak se říká, již dlouho setrvává v mlčení); a zde jsem na rozpacích, zda onu poctu přijmout, či nikoli: je v tom totiž také obsažena otázka o sídle duše (sedes animae), a to jak vzhledem k její smyslové receptivní schopnosti (facultas sensitive percipiendi), tak vzhledem k její schopnosti pohybové (facultas locomotiva). Hledá se tedy určité responsum, o něž by se vzhledem ke své pravomoci (forum competens) mohly přít dvě fakulty, fakulta lékařská, pokud jde o její anatomicko-fyziologický obor, a fakulta $f$ losofická, pokud jde o její obor psychologicko-metafyzický, kde - jako při každé snaze o spojenectví mezi těmi, kdo chtějí vše založit na empirických principech, a těmi, kdo žádají nejvyšší apriorní důvody (případ, který stále ještě nastává při pokusech o sjednocení čisté právní nauky s politikou, jakožto naukou empiricky-podmíněnou, nebo při pokusech o sjednocení čisté náboženské nauky s naukou zjevenou, která je stejně tak empiricky-podmíněná) - dochází k nepř́ijemnostem, spočívajícím

1 I. Kant, Aus Sömmering: Über das Organ der Seele, in: Werke in zehn Bänden, vyd. W. Weischedel, IX, Schriften zur Anthropologie, Geschichtsphilosophie, Politik und Pädagogik, I, Darmstadt, 1983, str. 255-259. Jde o vyjádření ke spisu lékaře a anatoma Samuela Thomase Sömmeringa Über das Organ der Seele (Königsberg 1796), jehož rukopis autor zaslal Kantovi k posouzení. Spis, shrnující Sömmeringova zkoumání mozku a nervového systému, je Kantovi dedikován, a Kantovo vyjádření je v něm přetištěno jako dodatek (str. 81-86). V Kantově korespondenci se zachovaly tři předlohy k tomuto textu, viz I. Kant, Gesammelte Schriften, XIII, vyd. Königlich Preußische Akademie der Wissenschaften, Berlin - Leipzig 1922, str. 397-414. Podrobnější informace lze nalézt např́ílad in: I. Kant, Anthropology, History, and Education, vyd. G. Zöller - R. B. Louden, Cambridge 2007, str. 219-221. - Pozn. př̀k1. 
pouze na sporu fakult, jimž ona otázka přísluší, pokud je universita (jakožto instituce objímající veškerou moudrost) o nějaké responsum žádána. - Kdo se v daném př́padě zavděčí lékaři jakožto fyziologu, ten popudífilosofa jakožto metafyzika. A naopak, kdo uspokojí tohoto, prohřeší se vůči fyziologovi.

To, co vlastně způsobuje nejednotu fakult ohledně společného smyslového nástroje, je však pojem sídla duše, a proto bude lépe ponechat ho zcela mimo hru; to lze oprávněně učinit tím spíše, že tento pojem požaduje lokální prítomnost připisující věci, která je pouze objektem vnitřního smyslu a která je potud určitelná pouze co do časových podmínek, prostorový vztah, ale právě tím si protiřečí, zatímco virtuálni prítomnost, která přísluší pouze k rozvažování, a právě proto není místní, poskytuje pojem, který umožňuje pojednat předloženou otázku (ohledně sensorium commune) pouze jako fyziologický úkol. - Nebot' i když se většina lidí domnívá, že cítí myšlení v hlavě, jde jen o chybu spočívající v subrepci, totiž v tom, že soud o prríčině počitku na určitém místě (mozku) je považován za počitek oné prř́činy na tomto místě, a že se pak připouští, že stopy na mozku, pocházející z dojmů, jež se zde uskutečňují, označované jako materiální ideje (Descartes), doprovázejí myšlenky podle asociačních zákonů: tyto hypotézy, byt' jsou velmi svévolné, přesto přinejmenším nečiní žádné sídlo duše nutným a nesměšují fyziologický úkol s metafyzickým. - Máme tedy co do činění jen s matérií, která umožňuje sjednocení veškerých smyslů-představ v mysli. ${ }^{2}-\mathrm{Ta}$ jediná, která se k tomu (jako sensorium commune) kvalifikuje, je podle Vašeho objevu založeném na detailním pitevním zkoumání obsažena v mozkové dutině, a je to pouze voda: jako bezprostřední orgán duše, který na jedné straně zde zakončená nervová zauzlení vzájemně odděluje, aby se počitky skrze tyto nesmísily, na druhé straně však působí, že spolu navzájem průběžně tvoří společenství, aby žádné z těchto počitků, ačkoli jsou recipovány stejnou myslí, přece nebyly mimo mysl (což je protimluv).

2 Myslí chápeme pouze schopnost (animus) syntetizující dané představy a působící jednotu empirické apercepce, nikoli ještě substanci (anima), co do její, od matérie zcela odlišné, povahy, od níž pak abstrahujeme; tím dospíváme k tomu, že pokud jde o myslící subjekt, nesmíme překračovat do metafyziky, nakolik ta má co do činění s čistým vědomím a jeho jednotou a priori v syntéze daných představ (s rozvažováním), nýbrž s obrazotvorností, ${ }^{a}$ jejímž názorům - jak se lze domnívat - (i bez přítomnosti jejich předmětu) jakožto empirickým představám odpovídají a k nějakému celku vnitřního názoru sebe sama patř́ dojmy v mozku (vlastně habitus reprodukce).

Textová varianta podle J. H. Tieftrunka: „nýbrž, protože zůstáváme ve fyziologii, máme co do činění pouze s obrazotvorností, jejímž názorům..." - Pozn. překl. 
Nyní však dospíváme k velké obtíži: jelikož voda jako kapalina nemůže být náležitě myšlena jako něco organizovaného, avšak bez organizace, tj. bez účelného a ve své formě trvajícího uspořádání částí, se žádná matérie nehodí $\mathrm{k}$ bezprostřednímu duševnímu orgánu, onen nádherný objev ještě nedosahuje svého cíle.

Kapalnou je stálá matérie, jejíž každá část může být uvnitř prostoru, který zaujímá, pohybována ze svého místa nejmenší silou. Tato vlastnost je však, jak se zdá, v rozporu s pojmem organizované matérie, kterou si myslíme jako stroj, tedy jako tuhou ${ }^{3}$ matérii odporující jistou silou posunování svých částí (a tedy také změně své vnitřní konfigurace); myslet si však onu vodu jako zčásti kapalnou a zčásti tuhou (např́klad jako krystalickou vlhkost $\mathrm{v}$ oku) by také znamenalo částečně přivést vniveč důvod, proč předpokládáme ono ustrojení bezprostředního smyslového orgánu, abychom vysvětlili jeho funkci.

Co kdybych místo mechanické organizace, spočívající na kladení částí vedle sebe tak, aby vznikl určitý tvar, navrhl organizaci dynamickou, která by spočívala na chemických principech (tak jako mechanická organizace spočívala na principech matematických), a která by tak mohla existovat spolu s kapalností oné látky? - Tak jako matematické členění prostoru a matérie, která ho zabírá (např́klad členění mozkové dutiny a vody, která ji vyplňuje), postupuje donekonečna, mohlo by, nakolik je nám známo, postupovat donekonečna (in indefinitum) také chemické členění jakožto členění dynamické (dělení různých druhů, které se vzájemně rozpouštějí v nějaké matérii). - Čistá, obyčejná voda, ještě donedávna považovaná za chemický prvek, je nyní prostřednictvím pneumatických pokusů dělena na dva různé druhy vzduchu. Každý z těchto druhů má v sobě, mimo svůj základ, ještě tepelnou látku, která snad potom může být prŕrodou rozkládána na látku světelnou a na jinou matérii, stejně jako světlo může být dále rozkládáno na různé barvy atd. Když k tomu připočteme, jak nezměrnou rozmanitost částečně prchavých látek dokáže z oné obyčejné vody vytvořit rostlinná říše, zřejmě prostřednictvím rozkládání a jiného způsobu spojování: pak si lze představit, jak rozmanité nástroje nacházejí nervy na svých zakončeních v mozkové vodě (která snad nemůže být ničím jiným než obyčejnou vodou), aby díky nim byly receptivní vůči smyslovému světu a recipročně na něj působily.

Pokud pak přijmeme jako hypotézu, že v základu mysli v empirickém myšlení, tj. $v$ analýze a syntéze daných smyslových představ, spočívá

3 Proti kapalnému (fluidum) musíme klást tuhé (rigidum), jak ho také v protikladu k prvnímu chápal Euler. Protikladem pevného je duté. 
schopnost nervi̊ rozkládat podle jejich rozmanitosti vodu mozkové dutiny v ony pralátky, a tak, uvolňováním jedné či druhé, rozehrávat různé počitky (například počitky světla prostřednictvím podnícených zrakových nervů nebo počitky zvuku prostřednictvím nervů sluchových atd.), ale tak, že tyto látky poté, co podnět ustane, se ihned znovu slijí: pak můžeme říci, že tato voda je průběžně organizována, aniž je však kdy organizovaná: tím se ovšem dosahuje právě téhož, co bylo zamýšleno trvalou organizací, totiž učinit pochopitelnou kolektivní jednotu veškerých smyslových představ ve společném orgánu (sensorium commune), ale pouze co do jeho chemického členění.

Vlastní úkol, jak je předložen Hallerem, ${ }^{4}$ tím však není vyřešen. Tento úkol není pouze fyziologický, nýbrž měl by také sloužit jako prostředek $\mathrm{k}$ tomu, aby byla představena jednota vědomí sebe sama (která náleží rozvažování) v prostorovém vztahu duše k orgánům mozku (který náleží k vnějšímu smyslu), tedy sídlo duše, jakožto její lokální př́ítomnost, což je úkol pro metafyziku, pro niž však není pouze úkolem neřešitelným, nýbrž také o sobě rozporným. - Nebot' mám-li učinit názorným místo svojí duše, tj. svého absolutního já, někde v prostoru, musím sám sebe vnímat právě tímtéž smyslem, jímž vnímám matérii, která mě bezprostředně obklopuje; stejně jako se to děje, když chci určit své místo ve světě jako člověk, totiž tak, že své tělo musím brát ve vztahu k jiným tělesům mimo mě. - Duše se pak může vnímat pouze prostřednictvím vnitřního smyslu, zatímco tělesa může vnímat (at' už zevnitř či zvenku) pouze prostřednictvím smyslů vnějších; nemůže si tedy pro sebe určit naprosto žádné místo, protože pro tento účel by musela učinit samu sebe předmětem vlastního vnějšího názoru a musela by se přmemístit mimo sebe, což si protiřečí. - Požadované řešení úkolu ohledně sídla duše, jenž je přičítán metafyzice, dospívá k nemožné velikosti $(\sqrt{-2})$, a na toho, kdo se ho chápe, můžeme spolu s Terentiem zvolat: nihilo plus agas, quam si des operam, ut cum ratione insanias,${ }^{5}$ avšak nelze se hněvat na fyziologa - jemuž stačí, že vysledoval, kde je to jen možné, pouhou dynamickou přítomnost až k prítomnosti bezprostřední -, že vyzval metafyzika, aby doplnil to, co ještě chybí.

\section{Přeložil Tomáš Kobližek}

4 Viz A. von Haller, Elementa physiologiae corporis humani, IV, Lausanne 1762, str. 395 n. - Pozn. přek1.

5 „[Bylo by to] stejně marné, tak jako pokoušet se šílet s rozumem.“ Terentius, Kleštěnec, přel. V. Šrámek, Praha 1969, str. 23. 